\section{UPAYA HUKUM TERHADAP PERLINDUNGAN DAN PELESTARIAN LINGKUNGAN LAUT INDONESIA BERDASARKAN UNCLOS $1982^{1}$ Oleh: Reivan Fernando Christ Bokong ${ }^{2}$ Hendrik B. Sompotan ${ }^{3}$ Imelda A. Tangkere ${ }^{4}$}

\section{ABSTRAK}

Tujuan dilakukannya penelitian ini adalah untuk mengetahui bagaimana upaya perlindungan dan pelestarian di lingkungan laut Indonesia menurut UNCLOS 1982 dan bagaimana pertanggungjawaban hukum bagi pelaku pencemaran lingkungan laut menurut hukum positif Indonesia. Dengan menggunakan metode peneltian yuridis normatif, disimpulkan: 1. UNCLOS 1982 sebagai landasan atau payung hukum internasional yang mengatur terkait tentang perindungan dan pelestarian lingkungan laut dimana dalam UNCLOS terdapat bagian tersendiri yang secara khusus mengatur mengenai perlindungan dan pelestarian lingkungan laut. Ketentuan-ketentuan yang mengatur mengenai perlindungan lingkungan laut terdapat dalam Bab XII (dua belas) UNCLOS 1982, yang pada intinya memuat mengenai perlindungan, pelestarian lingkungan laut, pencegahan, penguruangan, dan penguasaan pencemaran lingkungan laut. Negara peserta konvensi hukum laut 1982 atau UNCLOS mempunyai kewajiban untuk menaati semua ketentuan konvensi tersebut bernkenaan dengan perlindungan dan pelestariaan lingkungan laut. 2. UndangUndang Nomor 32 Tahun 2009 Tentang Pengelolaan dan Perlindungan Lingkungan Hidup merupakan hukum positif yang memayungi segala tindak tandus terkait dengan lingkungan hidup termasuk dengan pertanggungjwaban hukum bagi pelasku yang melakukan pencemaran lingkungan laut di Indonesia. Dimana dalam Undang-Undang ini terdapat tiga bentuk atau jalur pertanggungjawaban hukum yakni : pertanggungjawaban Administrasi,

\footnotetext{
${ }^{1}$ Artikel Skripsi

2 Mahasiswa pada Fakultas Hukum Unsrat, NIM : 14071101727

${ }^{3}$ Fakultas Hukum Unsrat, Magister IImu Hukum

${ }^{4}$ Fakultas Hukum Unsrat, Magister Ilmu Hukum
}

pertanggungjawaban

perdata, pertangungjawaban pidana.

Kata kunci: Upaya Hukum, Perlindungan Dan Pelestarian, Lingkungan Laut Indonesia

\section{PENDAHULUAN}

\section{A. Latar Belakang}

Negara kita merupakan negara kepulauan terbesar di dunia yang terletak pada posisi silang yang sangat strategis di antara dua benua dan dua samudra. Wilayah perairan indonesia menjadi jalur pelayaran internasional baik di perairan wilayah barat maupun timur. Namun demikian, jalur perairan di wilayah barat indonesia merupakan lalu lintas internasional sebagai Sea Lanes of Communications (SLOCS) dan Sea Lanes of Oil Trade (SLOT) bagi pengguna laut yang sangat strategis. Sebagian besar perairan wilayah barat merupakan jalur padat dan berbatasan langsung dengan negara-negara tetangga, yaitu: India, Thailand, Malaysia, Singapura, dan Vietnam. Jalur pelayaran tersebut dilalui oleh armadaarmada niaga yang bernilai strategis dan ekonomis tinggi. Fenomena itu menyebabkan kepercayaan dunia terhadap situasi keamanan di jalur ini berpengaruh langsung terhadap kemajuan negara-negara pantai. ${ }^{5}$

Situasi di kawasan regional semakin berkembang akibat eksalasi situasi keamanan yang terjadi di laut China selatan oleh klaim Nine Dash Line China terhadap wilayah laut yang bersinggungan dengan beberapa negara di Asia. Selain itu, dengan adanya kebijakan luar negeri China One Belt One Road (OBOR) yang bermuatan politik dan ekonomi serta kebijakan luar negeri Amerika Serikat Rebalancing Power atau Pivot to Asia yang menjadikan wilayah Asia Pasifik sebagai fokus kebijakan luar negerinya. Ditambah dengan situasi di semenanjung Korea akibat agresivitas Korea Utara dengan percobaan nuklirnya secara otomatis akan berdampak secara langsung maupun tidak langsung terhadap eksistensi Indonesia di kawasan regional maupun global.

Berdasarkan pasal 4 Peraturan Menteri ESDM Nomor 08 Tahun 2017 tentang Kontrak

\footnotetext{
5 Laksamana Muda TNI Aan Kurnia, S.Sos, Beetwen Threats \& Opportunities, 2017, hlm. iv.
} 
Bagi Hasil Gross Split menyebutkan bahwa kontrak bagi hasil Gross Split sebagaimana yang dimaksud dalam pasal 2 ayat 1 menggunakan mekanisme bagi hasil awal base split yang dapat disesuaikan dengan komponen variabel dan komponen progresif. Sementara pasal 5 ayat 1 menyebutkan bahwa dalam pelaksanaan kontrak bagi hasil Gross Split sebagaimana yang dimaksud pasal 4 ditetapkan, untuk minyak bumi sebesar $57 \%$ bagian negara dan $43 \%$ bagian kontraktor. sementara untuk gas bumi sebesar $52 \%$ bagian negara dan $48 \%$ bagian kontraktor. sedangkan ayat 2 menyebutkan bahwa bagi hasil awal sebagaimana yang dimaksud pada ayat 1 digunakan sebagai acuan dasar dalam penetapan bagi hasil pada saat persetujuan rencana pengembangan lapangan. ${ }^{6}$

Selain permasalahan disektor migas, indonesia juga masih memiliki permasalahan lainnya disektor lingkungan laut. Perkembangan masyarakat internasional menunjukan bahwa kualitas lingkungan laut tidak lagi dapat diabaikan kedudukannya dalam kehidupan manusia. Perhatian yang cukup dan penanganan yang serius harus segera dilakukan. Mengingat begitu pentingnya perlindungan terhadap lingkungan laut, maka didalam United Nations Convention on The Law of The Sea (UNCLOS) 1982 , terdapat bagian tersendiri yang secara khusus mengatur mengenai perlindungan, pelestarian lingkungan laut, pencegahan, pengurangan, dan penguasaan pencemaran laut.

Sejak tahun 1985, Indonesia telah meratifikasi UNCLOS 1982 melalui UU No. 17 Tahun 1985 tentang pengesahan UNCLOS 1982. Namun pada kenyataanya, permasalahan mengenai hukum laut semakin banyak. Meskipun sudah banyak kebijakan yang dikeluarkan oleh pemerintah, tetapi halhal tersebut belum mampu mengatasi permasalahan-permasalahan lingkungan laut yang ada. Kemajuan teknologi sering disebut sebagai salah satu penyebab terjadinya kerusakan lingkungan laut. Berkembangnya usaha-usaha eksplorasi dan eksploitasi minyak dilepas pantai dan semakin ramainya lalu-lintas kapal-kapal raksasa yg melalui

\footnotetext{
${ }^{6} \mathrm{Ibid}, \mathrm{hlm} .11$
}

perairan Indonesia, dan dengan semakin pentingnya lalu-lintas kapal-kapal nuklir, maka bahaya yang dihadapi negara indonesia terhadap keserasian dan kelestarian lingkungan lautnya juga akan semakin besar. Sehingga, dari sekarang sudah perlu mulai dipikirkan bagaimana cara menanggulangi bahaya-bahaya tersebut dimasa mendatang. ${ }^{7}$

\section{B. Perumusan Masalah}

1. Bagaimana upaya perlindungan dan pelestarian di lingkungan laut Indonesia menurut UNCLOS 1982.

2. Bagaimana pertanggungjawaban hukum bagi pelaku pencemaran lingkungan laut menurut hukum positif Indonesia?

\section{Metode Penelitian}

Secara umum metode penelitian diartikan sebagai cara ilmiah untuk mendapatkan data dengan tujuan dan kegunaan tertentu. Dalam penelitian ini, hal-hal yang perlu dijelaskan meliputi: jenis penelitian, sifat penelitian dan teknik. Jenis penelitian yang digunakan dalam penelitian ini adalah penelitian Hukum Normatif yuridis dimana penulis penulis meletakkan hukum sebagai sebuah bangunan sistem Norma. ${ }^{8}$

\section{PEMBAHASAN}

\section{A. Upaya Perlindungan dan Pelestarian Lingkungan Laut Indonesia Menurut UNCLOS 1982.}

Beberapa konsep upaya perlindungan dan pelesatrian lingkungan hidup di Indonesia, yang terbagi dalam perlindungan terhadap pencemaran lingkungan dan perlindungan terhadap sumber daya alam hayati di lingkungan laut.

1. Perlindungan Terhadap Pencemaran Lingkungan Laut di Indonesia

Pendekatan dasar konvensi terhadap pencemaran laut diletakan dalam Pasal 194196. Dalam Pasal 191 menyatakan bahwa Negara-Negara harus mengambil segala

7

http://catatanpenailahi.blogspot.com/2014/08/implem entasi-unclos-1982-terhadap.html?m=1, diakses pada 20 September 2019, Pukul : 20.32 Wita

${ }^{8}$ Mukti Fajar dan Yulianto Ahmad, Dualisme Penelitian Hukum Normatif dan empiris, 2010, hlm. 34. 
tindakan yang diperlukan untuk mencegah, mengurangi dan mengendalikan pencemaran lingkungan laut dari sumber apapun. Dalam mengambil tindakan-tindakan pencegahan, pengurangan dan mengendalikan pencemaran tersebut, setiap negara harus melakukannya dengan sedemekian rupa agar tidak memindahkan kerusakan atau bahya tersebut, dari suatu daerah ke daerah lain, atau mengubahnya dari suatu jenis pencemaran ke pencemaran lainnya. Kemudian Pasal 196 konvensi ini memberikan kewajiban kepada setiap Negara untuk mengambil segala tindak guna mencegah dan mengendalikan pencemaran lingkungan laut yang diakibatkan oleh penggunaan teknologi di bawah yurisdiksi atau pengawasannya. Hal tesebut dapat dilakukan misalnya dengan cara mengatur, menilai dan menganalisa berdasarkan metode ilmiah mengenai resiko atau akibat pencemaran lingkungan laut. ${ }^{9}$

Menurut Undang-Undang Nomor 32 Tahun 2009 Tentang Perlindungan dan Pengelolaan Lingkungan Hidup (UUPLH), perlindungan dan pengelolaan lingkungan hidup bertujuan untuk: "melindungi wilayah Negara Kesatuan Republik Indonesia dari pencemaran dan/atau kerusakan lingkungan hidup". Jika dikaitkan dengan lingkungan laut, ketentuan Pasal 3 huruf a UUPLH ini bertujuan untuk melindungi perairan di Indonesia dari berbagai kerusakan yang diakibatkan oleh kegiatan yang dilakukan di luar maupun didalam yurisdiksi Indonesia. ${ }^{10}$

Undang-Undang ini diberlakukan terhadap kegaitan-kegiatan yang menyebabkan kerusakan atau penceamran laut, yang dilakukan di dalam maupun diluar yurisdiksi Indonesia. Selanjutnya dalam Pasal 67 Undang-Undang ini menetukan bahwa "setiap orang berkewajiban memelihara kelestarian fungsi lingkungan hidup serta mencegah dan menanggulangi penemcaran dan perusakan lingkungan hidup". Karena itu, apabila terjadi pelanggaran terhadap ketentuan ini, asas tanggungjawab mutlak dapat diterapkan, sebagaimana yang diatur dalam Pasal 88 Undang-Undang ini. Ketentuan Pasal 88 UUPLH ini telah sejalan dengna ketentua yang terdapat dalam Pasal 235 UNCLOS 1982 mengenai tanggungjawab dan ganti rugi. ${ }^{11}$

Selain UUPLH, pengaturan hukum perlindungan laut juga dirumuskan dalam Perundang-undangan sektoral, yaitu UndangUndang Nomor 1 Tahun 1973 tentang Landas Kontinen Indonesia dan Undang-Undang Nomor 5 Tahun 1983 Tentang Zona Ekonomi Ekslusif Indonesia (ZEEI). Pasal 8 ayat (1) Undang-Undang Nomor 1 Tahun 1973, mewujudkan setiap orang yang melakukan kegaiatan-kegiatan di Landasa kontinen Indonesia agar mengambil langkah untuk mencegah terjadinya pencemaran air laut di landas kontinen Indonesia dan udara diatasnya. Kemudian dalam Pasal 8 UndangUndang Nomor 5 Tahun 1983 tentang ZEEI, mewajibkan kepada setiap orang yang melakukan di ZEEI untuk mengambil langkahlangkah guna mencegah, mengurangi dan menaggulangi pencemaran lingkungan laut. Sehingga apabila terjadi kerusakan dan pencemaran, maka setiap pelaku pengrusakan dan pencemaran tersebut akan dibebankan tanggungjawab mutlak dan membayar rehabilitasi lingkungan laut dengan segera dan dalam jumlah yang memadai. Selain tanggungjawab mutlak berupa ganti tugi, Undang-Undang ini juga memuat tentang saksi pidana terhadap pelaku pengrusakan atau pencemaran zona ekonomi ekslusif Indonesia. Ketentuan ini diatur dalam Pasal 16 ayat (3). ${ }^{12}$

Selanjutnya Pemerintah Indonesia kemudian mengeluarkan suatu aturan dalam bentuk Peraturan Pemerintah (PP) yang mengatur pencemaran secara khusus yaitu Peraturan Pemerintah Republik Indonesia Nomor 19 Tahun 1999 tentang Pengendalian Pencemaran dan/atau Pengrusakan Laut. PP Nomor 19 Tahun 1999 menyatakan bahwa setia orang penanggungjawab usaha dan/atau kegiatan dilaran melakukan perbuatan yang dapat menimbulkan pencemaran/kerusakan laut. Selain itu PP Nomor 19 Tahun 1999 juga mengisyaratkan bahwa setiap orang atau penanggungjawab usaha dan/atau kegiatan tidak hanya wajib melakukan pencegahan terjadinya penceamran lingkungan, namun

${ }^{11} \mathrm{lbid}$

12 Ibid 
wajib pula melakukan penanggulangan pencemaran da/atau perusakan laut yang diakibatkan oleh kegiatannya, melakukan pemulihan laut. ${ }^{13}$

Meskipun telah ada peraturan yang mengatur secara khusus mengenai penceamran yaitu PP Nomor 19 Tahun 1999. Tetapi, muatan materi dari PP tersebut belum memadai dan belum mengakomodir semua ketentuan-ketentuan yang diwajibkan UNCLOS 1982 dibidang perlindungan lingkungan laut khususnya dalam Bab XII (Pasal 207 sampai 212) UNCLOS 1982. Selanjutnya, ketentua mengenai perlindungan lingkunga laut juga terdapat dalam UndangUndang Nomor 17 Tahun 2008 tentang Pelayaran yang mana dalam Undang-Undang tersebut mengamantkan Pelrindungan Lingkungan Maritim di dalamnya. Perlindungan dilingkungan maritim yang dimaksud dalam Undang-Undang ini adalah kondisi terpenuhinya prosedur dan persyaratan pencegahan dan penaggulangan pencemaran dari kegiatan kepelabuhannan, pengoprasian kapal. Pengangkutan limbah dan bahan berbahaya di perairan, dan pembuangan limbah perairan. ${ }^{14}$

2. Perlindungan dan Pengelolaan Sumber Daya Alam Hayati di Laut.

Dalam Undang-undang Nomor 31 Tahun 2004 tentang Perikanan menyatakan bahwa wilayah pengelolaan perikanan Republik Indonesia, meliputi perairan Indonesia dan ZEEI. Pengelolaan perikanan dalam wilayah pengelolaan perikanan Republik Indonesia bertujuan agar tercapainya pemanfaatan yang optimal dan berkelanjutan serta terjaminnya kelestarian sumber daya ikan. Kemudian, di dalam Undang-undang Nomor 45 Tahun 2009 tentang Perubahan Atas Undang-undang Nomor 31 Tahun 2004 tentang Perikanan menyatakan bahwa setiap orang dilarang memiliki, menguasai, membawa dan/atau menggunakan alat penangkapan ikan dan/atau alat bantu penangkapan ikan yang mengganggu dan merusak keberlanjutan sumber daya ikan di kapal penangkap ikan di wilayah pengelolaan perikanan Negara Republik Indonesia. Jadi,

13 Ibid ketentuan Undang-undang Perikanan telah mengimplementasikan beberapa ketentuan UNCLOS 1982. Selanjutnya, Keputusan Menteri Kelautan dan Perikanan Nomor 38/Men/2004 tentang Pedoman Umum Pengelolaan Terumbu Karang. Dengan berpegang pada pedoman ini diharapkan pengelolaan terumbu karang dilakukan secara seimbang antara pemanfaatan dan pelestarian. ${ }^{15}$

3. Implementasi Hukum tentang Perlindugan Pelestarian Lingkungan Laut di Indonesia.

PP No 19 Tahun 1999 tentang Pengendalian Pencemaran dan atau Perusakan Laut, UU Nomor 6 Tahun 1996 menggariskan Prinsip tentang Perlindungan Lingkungan laut dengan menyebutkan bahwa Pemanfaatan Pengelolaan, Perlindungan Dan Pelestarian Lingkungan perairan Indonesia dilakukan berdasarkan Peraturan perundang- undangan nasional dan hukum internasional. Demikian juga tentang masalah administrasi Dan yurisdiksi Perlindungan, Dan pelestarian Lingkungan perairan Indonesia dilaksanakan berdasarkan Peraturan perundang-undangan.

\section{B. Pertanggungjawaban Hukum Bagi Pihak} Yang Melakukan Pencemaran Lingkungan Laut Menurut Hukum Positif di Indonesia.

Undang-undang Nomor 32 Tahun 2009 tentang Pengelolaan dan Perlindungan Lingkungan Laut (UUPLH) merupakan payung hukum dalam setiap aktivitas lingkungan laut di Indonesia, termasuk pemberian sanksi atau bentuk pertanggungjawaban hukum bagi pelaku pencemaran lingkungan laut di Indonesia. Dalam ketentuan UUPLH tersebut menyatakan bahwa terdapat beberapa bentuk atau jalur pertanggungjawaban hukum bagi pelaku yang melakukan pencemaran lingkungan laut di Indonesia diantaranya adalah melalui jalur pertanggungjwaban administrasi,

15 http://www.bppp-tegal.com/web/index.php/201708-26-04-36-53/penangkapan-ikan/589-implementasiperlindungan-dan-pelestarian-lingkungan-laut-menurutunclos-1982-di-indonesia, diakses pada 07 Oktober 2019, Pukul : 14.17 Wita 
pertanggungjawaban perdata, dan melalui pertanggungjawaban pidana sebagai sarana terkahir dalam penerapan sanksi bagi pelaku tindak pidana atau dalam hukum dikenal dengan istilah "ultimum remedium". Dikalangan para sarjana hukum atau orang yang setidaknya belajar hukum, hukum pidana itu merupakan ultimum remedium. Maksud dari istilah tersebut adalah hukum pidana itu merupakan senjata/obat terakhir dalam penegakan hukum. Istilah tersebut memiliki makna bahwa apabila suatu perkara dapat diselesaikan dengan jalur lain (kekeluargaan, negosiasi, mediasi, sanksi administratif), maka hendaklah jalur tersebut dilalui terlebih dahulu. ${ }^{16}$

1. Tanggung Jawab Administrasi

Pengaturan penegakan hukum lingkungan melalui sanksi administrasi disebabkan penegakan hukum administrasi mempunyai fungsi sebagai instrumen pengendalian, pencegahan, dan penanggulangan perbuatan yang dilarang oleh ketentuan-ketentuan lingkungan hidup. Melalui sanksi administasi dimaksudkan agar perbuatan pelanggaran itu dihentikan, sehingga sanksi administrasi merupakan instrument yuridis yang bersifat preventif dan represif non-yustisial untuk mengakhiri atau menghentikan pelanggaran ketentuan-ketentuan yang tercantum dalam persyaratan perlindungan dan pengelolaan lingkungan hidup, selain bersifat represif, sanksi administrasi juga mempunya sifat reparatoir, artinya memulihkan keadaan semula, oleh karena itu pendayagunaan sanksi administrasi dalam penegakan hukum lingkungan penting bagi upaya pemulihan media lingkungan yang rusak atau tercemar.

Berbeda dengan sanksi perdata maupun sanksi pidana, penerapan sanksi administrasi oleh pejabat administrasi dilakukan tanpa harus melalui proses pengadilan (nonyustisial), sehingga penerapan sanksi administrasi relative lebih cepat dibandingkan dengan sanksi lainnya dalam upaya untuk menegakkan hukum lingkungan. Yang tak kalah pentingnya dari penerapan sanksi

\footnotetext{
16 https://www.qureta.com/post/hukum-pidanasebagai-ultimum-remedium, diakses pada 15 Oktober 2019, Pukul 23.04 Wita
}

administrasi ini adalah terbuka ruang dan kesempatan untuk partisipasi masyarakat.

Penegakan hukum dibidang administrasi merupakan suatu instrumen usaha untuk perlindungan dan pengelolaan lingkungan hidup, didasarkan atas dua instrument penting yaitu pengwasan dan penerapan sanksi administrative pengawasan dilakukan untuk mengetahui tingkat ketaatan penanggungjawab usaha dan/atau kegiatan terhadap: ${ }^{17}$

Pelaksanaan penerapan sanksi administratif bagi setiap pelaku pengerusakan lingkungan laut/lingkungan hidup memiliki tahap-tahap untuk dapat berlangsungnya kepastian hukum, dan dapat di berikan kepada setiap pelaku melalui tanggung jawab secara administrative.

\section{a. Teguran tertulis}

Sanksi Administratif teguran tertulis adalah sanksi yang diterapkan kepada penganggung jawab usaha dan/atau kegiatan dalam hal penanggung jawab usaha dan/atau kegiatan telah melakukan pelanggaran peraturan perundang-undangan dan persyaratan yang ditentukan dalam izin lingkungan. Namun pelanggaran tersebut baik secara tata kelola lingkungan hidup yang baik mapun secara teknis masih dapat dilakukan perbaikan dan pula belum menimbulkan dampak negatif terhadap lingkungan hidup. Pelanggaran tersebut harus dibuktikan dan dipastikan belum menimbulkan dampak negatif terhadap lingkungan hidup berupa pencemaran dan/atau perusakan, misalnya ${ }^{18}$

1) Bersifat administratif, antara lain:

a) tidak menyampaikan laporan;

b) tidak memiliki log book dan neraca limbah B3;

c) tidak memiliki label dan simbol limbah B3.

2) Bersifat teknis tetapi perbaikannya bersifat ringan yaitu perbaikan yang dapat dilakukan secara langsung tidak

\footnotetext{
17 Undang-undang Nomor 32 Tahun 2009 Tentang Pengelolaan dan perlindungan lingkungan hidup (UUPPLH).

18 Peraturan Menteri Lingkungan Hidup RI Nomor 2 Tahun 2013 Tentang Pedoman Penerapan Sanksi Administratif di Bidang Perlindungan dan Pengelolaan Lingkungan Hidup.
} 
memerlukan waktu yang lama,tidak memerlukan penggunaan teknologi tinggi, tidak memerlukan penanganan oleh ahli, tidak memerlukan biaya tinggi.

b. Paksaan Pemerintah

Paksaan pemerintah adalah sanksi administratif berupa tindakan nyata untuk menghentikan pelanggaran dan/atau memulihkan dalam keadaan semula. Penerapan sanksi paksaan pemerintah dapat dilakukan terhadap penanggung jawab usaha dan/atau kegiatan dengan terlebih dahulu diberikan teguran tertulis. Adapun penerapan sanksi paksaan pemerintah dapat dijatuhkan pula tanpa didahului dengan teguran tertulis apabila pelanggaran yang dilakukan menimbulka: ${ }^{19}$

1) ancaman yang sangat serius bagi manusia dan lingkungan hidup;

2) dampak yang lebih besar dan lebih luas jika tidak segera dihentikan pencemaran dan/atau perusakannya; dan/atau

3) kerugian yang lebih besar bagi lingkungan hidup jika tidak segera dihentikan pencemaran dan/atau perusakannya.

c. Pembekuan Izin Lingkungan dan/atau Izin Perlindungan dan Pengelolaan Lingkungan Hidup

\section{Tanggung jawab Perdata}

Penegakan hukum lingkungan dapat juga melalui jalur hokum perdata. Jalur ini di Indonesia kurang disenangi karena proses yang berlarut-larut di pengadilan. Hampir semua kasus perdata diupaya ke pengadilan yang tertinggi untuk kasasi karena selalu tidak puasnya para pihak yang kalah. Bahkan, ada kecenderungan orang sengaja mengulur waktu dengan selalu mempergunakan upaya hukum, bahkan walaupun kurang beralasan biasa dilanjutkan pula ke peninjauan kembali. Sesudah ada putusan itu masih juga sering sulit untuk dilaksanakan. ${ }^{20}$

\footnotetext{
19 Pasal 4 ayat (1) Peraturan Menteri Lingkungan Hidup RI Nomor 2 Tahun 2013 Tentang Pedoman Penerapan Sanksi Administratif di Bidang Perlindungan dan Pengelolaan Lingkungan Hidup.

${ }^{20}$ Andi Hamzah, 2005, Penegakan Hukum Lingkungan, Jakarta: Sinar Grafika, HIm. 89
}

Sengketa (perdata) lingkungan hidup dapat ditempuh melalui pengadilan atau di luar pengadilan berdasarkan pilihan sukarela para pihak yang bersangkutan. Jika usaha diluar pengadilan yang dipilih itu tidak berhasil maka salah satu atau para pihak dapat ditempuh jalur pengadilan. Gugatan melalui pengadilan hanya dapat di tempuh apabila upaya penyelesaian sengketa diluar pengadilan yang dipilih dinyatkan tidak berhasil oleh satu atau para pihak yang bersengketa. ${ }^{21}$

Namun dalam penerapan lebih khususnya tanggung jawab terhadap pelaku pengerusakan lingkungan laut dalam Kitab Undang Undang Hukum Perdata terlalu sempit pengertian secara pasti mengenai perbuatan melawan hukum. Pengertian perbuatan melawan hukum dapat disimpulkan dari dua pasal dalam KUHPerdata yang mengatur tentang ganti rugi akibat adanya perbuatan melawan hukum. Kedua pasal itu yakni Pasal 1365 KUHPerdata yang menyatakan bahwa "Tiap perbuatan yang melawan hukum dan membawa kerugian kepada orang lain, mewajibkan orang yang menimbulkan kerugian itu karena kesalahannya untuk mengganti kerugian tersebut" dan Pasal 1366 KUHPerdata yang berbunyi "Setiap orang bertanggung jawab tidak saja untuk kerugian yang disebabkan karena perbuatannya, tetapi juga untuk kerugian yang disebabkan karena kelalaian atau kurang hati-hatinya."

\section{Pertanggungjawaban Pidana}

Pertanggungjawaban pidana mengandung asas kesalahan (asas culpabilitas), yang didasarkan pada keseimbangan monodualistik bahwa asas kesalahan yang didasarkan pada nilai keadilan harus disejajarkan berpasangan dengan asas legalitas yang didasarkan pada nilai kepastian. Walaupun Konsep berprinsip bahwa pertanggungjawaban pidana berdasarkan kesalahan, namun dalam beberapa hal tidak menutup kemungkinan adanya pertanggungjawaban pengganti (vicarious liability) dan pertanggungjawaban

\footnotetext{
21 Pasal 84 Undang-Undang Nomor 32 Tahun 2009 Tentang Perlindungan dan Pengelolaan Lingkungan Hidup (UUPPLH)
} 
yang ketat (strict liability). Masalah kesesatan (error) baik kesesatan mengenai keadaannya (error facti) maupun kesesatan mengenai hukumnya sesuai dengan konsep merupakan salah satu alasan pemaaf sehingga pelaku tidak dipidana kecuali kesesatannya itu patut dipersalahkan kepadanya. ${ }^{22}$

Pertanggungjawaban pidana harus memperhatikan bahwa hukum pidana harus digunakan untuk mewujudkan masyarakat adil dan makmur merata materiil dan spirituil. Hukum pidana tersebut digunakan untuk mencegah atau menanggulangi perbuatan yang tidak dikehendaki. Selain itu penggunaan sarana hukum pidana dengan sanksi yang negatif harus memperhatikan biaya dan kemampuan daya kerja dari insitusi terkait, sehingga jangan sampai ada kelampauan beban tugas (overbelasting) dalam melaksanakannya. ${ }^{23}$

Telah disebutkan sebelumnya bahwa dalam hal penegakan hukum bagi pelaku pencemaran lingkungan hidup terlebih khusus pencemaran lingkungan laut, hukum pidana hadir sebagai obat terakhir atau sarana terakhir (ultimum remedium). Ultimum remedium dapat dilihat dalam ketentuan UUPLH. Walaupun dalam ketentuan tersebut tidak dijelaskan secara eksplisit tentang definisi dari asas ultimum remedium, namun hal itu terdapat dalam Pasal 100 yang menyebutkan : ${ }^{24}$

(1) Setiap orang yang melanggar baku mutu air limbah, baku mutu emisi, atau baku mutu gangguan dipidana, dengan pidana penjara paling lama 3 (tiga) tahun dan denda paling banyak Rp3.000.000.000,00 (tiga miliar rupiah).

(2) Tindak pidana sebagaimana dimaksud pada ayat (1) hanya dapat dikenakan apabila sanksi administratif yang telah dijatuhkan tidak dipatuhi atau pelanggaran dilakukan lebih dari satu kali".

Berdasarkan ketentuan Pasal 100 ayat 2 tersebut maka dapat diketahui bahwa ada

22 Barda Nawawi Arief, 2001, Masalah Penegakan Hukum dan Kebijakan Peanggulangan Kejahatan, Bandung : PT. Citra Aditya Bakti, HIm. 23

${ }^{23} \mathrm{Ibid}, \mathrm{HIm} .23$

24 Undang-Undang RI Nomor 32 Tahun 2009, Pasal 100 ayat (1) dan (2) pemberlakuan asas ultimum remedium, dimana pemidanaan pada pasal 100 ayat 1 dapat dikenakan bilamana sanksi administrative yang sudah diputus oleh pemerintah tidak dipatuhi oleh pemegang usaha dan kegiatan yang memanfaatkan lingkungan. Selain itu, asas ultimum remedium dalam undang-undang tersebut terdapat pada penjelasan umum angka 6 yang menyatakan $:^{25}$ "penegakan hukum pidana lingkungan hidup tetap memperhatikan azas ultimum remedium yang mewajibkan penerapan penegakkan hukum pidana sebagai upaya terakhir setelah penerapan penegakkan hukum administrasi dianggap tidak berhasil. Penerapan azas ultimum remedium ini hanya berlaku bagi tindak pidana formil tertentu, yaitu pemidanaan terhadap pelanggaran baku mutu air limbah, emisi dan gangguan. tetap memperhatikan azas ultimum remedium yang mewajibkan penerapan penegakkan hukum pidana sebagai upaya terakhir setelah penerapan penegakkan hukum administrasi dianggap tidak berhasil. Penerapan azas ultimum remedium ini hanya berlaku bagi tindak pidana formil tertentu, yaitu pemidanaan terhadap pelanggaran baku mutu air limbah, emisi dan gangguan.

\section{PENUTUP}

\section{A. Kesimpulan}

1. UNCLOS 1982 sebagai landasan atau payung hukum internasional yang mengatur terkait tentang perindungan dan pelestarian lingkungan laut dimana dalam UNCLOS terdapat bagian tersendiri yang secara khusus mengatur mengenai perlindungan dan pelestarian lingkungan laut. Ketentuan-ketentuan yang mengatur mengenai perlindungan lingkungan laut terdapat dalam Bab XII (dua belas) UNCLOS 1982, yang pada intinya memuat mengenai perlindungan, pelestarian lingkungan laut, pencegahan, penguruangan, dan penguasaan pencemaran lingkungan laut. Negara peserta konvensi hukum laut 1982 atau UNCLOS mempunyai

25 Undang-Undang RI Nomor 32 Tahun 2009, Penjelasana Umum angka 6 
kewajiban untuk menaati semua ketentuan konvensi tersebut bernkenaan dengan perlindungan dan pelestariaan lingkungan laut.

2. Undang-Undang Nomor 32 Tahun 2009 Tentang Pengelolaan dan Perlindungan Lingkungan Hidup merupakan hukum positif yang memayungi segala tindak tandus terkait dengan lingkungan hidup termasuk dengan pertanggungjwaban hukum bagi pelasku yang melakukan pencemaran lingkungan laut di Indonesia. Dimana dalam UndangUndang ini terdapat tiga bentuk atau jalur pertanggungjawaban hukum yakni : pertanggungjawaban Administrasi, pertanggungjawaban perdata, pertangungjawaban pidana.

\section{B. Saran}

1. Melihat banyaknya kebijakan ataupun peraturan yang terpencar terkait dengan perlindungan dan pelestarian lingkungan laut yang merupakan ratifikasi dari UNCLOS 1982, sehingga penulis menyarankan agara adanya suatu aturan yang baku dan tegas terkait upaya pelestarian dan perlindungan lingkungan laut di Indonesia agar supaya menghindari kebingungan hukum, dan memberikan pengaturan terkait upaya pencegahan secara konkrit.

2. Pertanggungjawaban Hukum Bagi Pelaku Pencemaran Lingkungan Laut Menurut Hukum Positif Di Indonesia. Bahwa pertanggungjawaban bagi pelaku pencemaran lingkungan laut harus lebih efisien dan dipertegas lagi karena dalam tanggungjawab administrasi, perdata, pidana masih belum secara tegas mengatur mengenai kualifikasi tindak pencemaran lingkungan laut yang lebih khusus perbuatan seperti apa yang bisa di kategorikan sebagai tanggungjawab administrasi, perdata, maupun pidana.

\section{DAFTAR PUSTAKA}

Andi Hamzah, 2005. Penegakan Hukum Lingkungan. Jakarta: Sinar Grafika.
Barda Nawawi Arief, 2001. Masalah

Penegakan Hukum dan Kebijakan

Peanggulangan Kejahatan. Bandung :

PT. Citra Aditya Bakti.

Djalal Hasjim, 1979, Perjuangan Indonesia Di Bidang Hukum Laut, Bandung : Bina Cipta.

Djaja S. Meliala, 2014. Hukum Perdata Dalam Perspektif BW. Bandung: Nuansa Aulia.

Laksamana Muda TNI Aan Kurnia, S.Sos, 2017. Beetwen Threats \& Opportunities. Jakarta: PetroEnergi-Huta.

Mas Achmad Santosa, 2016. Alam pun Butuh Hukum \& Keadilan. Cilegon. PT. Asa Prima Abadi.

Mukti Fajar dan Yulianto Ahmad, 2010. Dualisme Penelitian Hukum Normatif dan empiris. Yogyakarta: Pustaka Pelajar.

Moh Nazir, 1988. Metode Penelitian. Jakarta: Ghalia Indonesia.

Muchsin, 2003, Perlindungan dan Kepastian Hukum Bagi Investor Di Indonesia, Surakarta; Magister IImu Hukum Program Pascasarjana Universitas Sebelas Maret.

Mochtar Kusumaatmadja, 1978. Bunga rampai Hukum Laut. Bandung : Bina Cipta.

Philipus M. Hadjon. 1987. Perlindungan hukum bagi rakyat Indonesia. Surabaya : Bina Ilmu

Syahrul Machmud, 2012, Penegakan Hukum Lingkungan Indonesia, Yogyakarta : Graha IImu.

Setiono, 2004. Rule of Law (Supremasi Hukum). Surakarta : Magister Ilmu Hukum Program Pascasarjana Universitas Sebelas Maret.

Peraturan Menteri Lingkungan Hidup RI Nomor 2, Tahun 2013. Tentang Pedoman Penerapan Sanksi Administratif di Bidang Perlindungan dan Pengelolaan Lingkungan Hidup.

Pasal 4 ayat (1) Peraturan Menteri Lingkungan Hidup RI Nomor 2 Tahun 2013 Tentang Pedoman Penerapan Sanksi Administratif di Bidang Perlindungan dan Pengelolaan Lingkungan Hidup.

Pasal 84 Undang-Undang Nomor 32 Tahun 2009 Tentang Perlindungan dan 
Pengelolaan Lingkungan Hidup (UUPPLH)

Undang-undang Nomor 32 Tahun 2009 Tentang Pengelolaan dan perlindungan lingkungan hidup (UUPPLH).

Undang-Undang RI Nomor 32 Tahun 2009, Pasal 100 ayat (1) dan (2).

Undang-Undang RI Nomor 32 Tahun 2009, Penjelasana Umum angka 6

Undang-Undang Nomor 45 Tahun 2009 Perubahan Atas Undang-Undang Nomor 31 Tahun 2004 Tentang Perikanan.

Kitab Undang-Undang Hukum Acara Pidana Pasal 1 butir 12 .

file:///C:/Users/user/Downloads/1431-26921-SM.pdf, diakses pada 16 Oktober 2019.

http://catatanpenailahi.blogspot.com/2014/0 8/implementasi-unclos-1982terhadap.html?m=1, diakses pada 20 September 2019.

https://text-

id.123dok.com/document/dy4kk3k5qpengertian-upaya-pengertianpeningkatan.html, diakses pada 22 September 2019.

http://www.jejakpendidikan.com/2016/12/p engertian-upaya.html, diakses pada 22 September 2019.

https://www.ruangguru.co.id/40-pengertianhukum-secara-umum-dan-definisinyamenurut-para-ahli/, diakses pada 22 September 2019.

https://abstrak.uns.ac.id/wisuda/upload/E00 12177 bab2.pdf, diaskes pada 22 September 2019.

http://repository.ump.ac.id/4588/3/SUFI\%20 NUR\%20ABIDAH\%20BAB\%20II.pdf, diakses pada 23 September 2019.

http://repository.ump.ac.id/4588/3/SUFI\%20 NUR\%20ABIDAH\%20BAB\%20II.pdf, diakses pada 23 September 2019. https://itsiin.blogspot.com/2016/04/jurnalperlindungan-dan-pelestarian.html, diakses pada 07 Oktober 2019.

https://catatanpenailahi.blogspot.com/2014/ 08/implementasi-unclos-1982terhadap.html, diakses pada 07 Oktober 2019.

https://catatanpenailahi.blogspot.com/2014/ 08/implementasi-unclos-1982- terhadap.html, diakses pada 07 Oktober 2019.

http://www.bppptegal.com/web/index.php/2017-08-2604-36-53/penangkapan-ikan/589implementasi-perlindungan-danpelestarian-lingkungan-laut-menurutunclos-1982-di-indonesia, diakses pada 07 Oktober 2019.

https://www.qureta.com/post/hukumpidana-sebagai-ultimum-remedium, diakses pada 15 Oktober 2019.

http://sanksiadministratif.blogspot.com/2015 104/makalah-sanksi-administratif.html, diakses pada 16 Oktober 2019.

https://blogmhariyanto.blogspot.com/2016/0 1/tindak-pidana-lingkunganhidup.html, diakses pada 16 Oktober 2019.

https://hulondalo.id/sanksi-pencemaranlingkungan-hidup/, diakses pada 16 Oktober 2019. 